\title{
Alat Monitoring Beban Trafo Tiga Phasa Menggunakan Arduino Berbasis Web
}

\author{
Ali Usman Nasution ${ }^{1}$, Sukardi $^{2}$ \\ 1,2Universitas Negeri Padang \\ Jl. Prof Dr. Hamka Air Tawar, Padang \\ aliusmannst23@gmail.com,sukardiunp@gmail.com
}

\begin{abstract}
Electricity has become a secondary human need, where all aspects of human life are connected to electricity. Therefore, in distributing electrical energy to consumers, it must always be maintained to its stability. During the distribution of electrical energy, the disturbance that often occurs is the instability of the load on the transformer, this disturbance will cause the flow of current to the neutral conductor, and more severely it will cause damage to the transformer itself. Therefore, it is necessary to make a web-based microcontroller-based traffic load monitoring tool, so that in the event of load instability it will quickly be detected. And this will give time in transformer load monitoring that can be carried out directly to the transformer with a predetermined schedule. The sct013 sensor installed on the transformer will read the current and the zmpt101b sensor will read the voltage from the transformer, and the readings will be processed by Arduino Mega 2560 , the results of the processing will be displayed on the $L C D$ in the form of date, voltage, current, and power. In addition, the results of the sensor readings that have been processed by Arduino are sent to the database that has been created. The process of sending data from Arduino is carried out by the esp8266-01 module which has been configured with Arduino. So that monitoring trafo load can be seen at any time on the alinasution.epizy.com website.
\end{abstract}

Keywords - Arduino Mega, Sensor SCT013, Sensor ZMPT101B, Modul Wifi Esp8266-01.

\begin{abstract}
Abstrak - Listrik sudah merupakan menjadi kebutuhan sekunder manusia, yang dimana segala segi kehidupan manusia sudah terkoneksi ke listrik. Maka dari itu pada pendistribusian energy listrikke konsumen harus slalu terjaga ke stabilannya. Padasaat pendistribusian energy listruk, gangguan yang sering terjadi adalah gangguan ketidakstabilan beban pada trafo, gangguan ini akan megakibatkan mangalirnya arus pada penghantar netral, dan lebih parah akan mengkibatkan kerusakan pada transformator itu sendiri. Maka oleh karena itu, perlu dibuat suatu alat monitoring beban trafo berbasis mikrokontroler berbasis web, sehingga jika terjadi ketidak stabilan beban akan bisa dengan cepat dapat dideteksi. Dan ini akan menghemat waktu dalam pemonitoringan beban transformator yang masih dilakukan secara langsung ke tempat transformator tersebut dengan jadwal yang telah ditentukan. Sensor sct013 yang dipasang pada trafo tersebut akan membaca arus dan sensor zmpt101b akan membaca tegangan dari trafo tersebut, dan hasil pembacaan tersebut akan di diolah oleh arduino mega 2560 , hasil dari pengolahan tersebut akan di tampilkan dalam lcd berupa tanggal, tegangn, arus, dan daya. Selain itu hasil dari pembacaan sensor yang telah di olah arduino ini dikirim ke database yang telah dibauat. Proses pengiriman data dari arduino ini dilakukan oleh modul esp8266-01 yang telah di konfigurasi dengan arduino. Sehingga pemonitoringan beban trafo bisa di lihat kapan pun di website alinasution.epizy.com.
\end{abstract}

Kata kunci-Arduino Mega, Sensor SCT013, Sensor ZMPT101B, Modul Wifi Esp8266-01.

\section{Pendahuluan}

Listrik sudah memegang peranan yang penting dalam kehidupan manusia, karena sebagian besar peralatan yang dipergunakan oleh manusia untuk menyelesaikan sebuah pekerjaan kebanyakan sudah menggunakan energi listrik.[1] Oleh karena itu, stabilitas dan kontinuitas dalam sistem pendistribusian energy listrik harus selalu terjaga supaya dapat digunakan oleh konsumen.[2] Dalam menjaga stabilitas sistem pendistribusian energy listrik diperlukan kualitas daya dan pembebanan pada transformator distribusi. Dengan begitu dalam pendistribusian daya ke konsumen harus diperhatikan juga ketidakseimbangan beban yang digunakan konsumen.[3] Dalam proses penyaluran energi listrik fenomena ketidakseimbangan memang selalu menjadi isu yang sangat penting, penomena ini muncul ketika perbedaan prioritas pada pelanggan.[4] Daya yang disuplay ke transformator tidak sama dengan daya dikeluarkan atau beban dimana terdapat daya input pada transformator sebagian yang menghilang ketika memiliki komponen reaktif, dan ada juga yang disebabkan pergeseran fasa antar tegangan input dan tegangan output yang mana mengakibatkan rugi-rugi pada transformator.[5] Ketidakseimbangan beban pada setiap fasa dapat mengganggu kinerja transformator dalam pendistribusian energi listrik. Gangguan ini akan menimbulkan kerugian dari berbagai pihak, baik pada konsumen dan perusahaan penyedia tenaga listrik. Oleh sebab itu perlu dibuat suatu system yang mengatur 
pemeliharaan transformator yang baik, demi menjaga keandalan transformator distribusi $20 \mathrm{kV}$. [6]

Kendala-kendala dari pemeliharaan transformator yang dilaksanakan di PT PLN (Persero), disebabkan belum adanya monitoring secara real time untuk mengetahui kondisi dari transformator.[7] Cara pemonitoringan yang dilakukan selama ini dalam melakukan pemeliharaan transformator adalah dengan pemeliharaan secara bulanan yang dimana dilakukan secara manual dan tidak memungkinkan untuk mendeteksi gangguan yang terjadi secara dini pada transformator.[8] PT. PLN hanya melakukan pemeliharaan rutin menurut jadwal dengan waktu tertentu, dan sangat sulit mendeteksi kondisi dari transformator yang mengalami gangguan tersebut bila terjadi gangguan diluar jadwal pemeliharaan transformtor tersebut.[9]

Berbagai penelitian sudah banyak tentang monitoring beban trafo ini juga sudah pernah dibuat, diantaranya monitoring dan proteksi tegangan panel 3 fasa dengan menggunakan sensor tegangan zmpt101b.[10] Berdasarkan kondisi dari latar belakang tersebut, penulis membuat ide dengan membuat alat monitoring beban trafo tiga fasa berbasis mikrokontroler menggunakan web. Dimana alat ini akan membanca beban dari trafo tersebut dan mengirimnya ke database, sehingga hasil dari pengukuran beban trafo tersebut dapat dilihat melalui website dari alat tersebut. Di dalam web tersebut akan ditampilkan hasil dari pengukuran beban trafo tersebut dalam bentuk table dan grafik. Dalam pembuatan alat monitoring beban trafo ini penulis menggunakan sensor tegangan zmpt101b, sensor arus sct103, arduino mega, rtc, dan esp8266-01.

\section{METODE PENELITIAN}

A. Dasar Teori

1) Arduino Mega

Arduino mega merupakan papan rangkaian system minimum yang bersipat open source, jenis ini menggunakan ic jenis 2560. Perbedaannya dengan arduino jenis yang lain adalah di jumlah kakinya, Jumlah kaki arduino mega yaitu 56. Bahasa pemrograman untuk arduino adalah menggunakan bahasa pemrograman $\mathrm{C}$ yang di tulis dalam aplikasi arduino Ide.

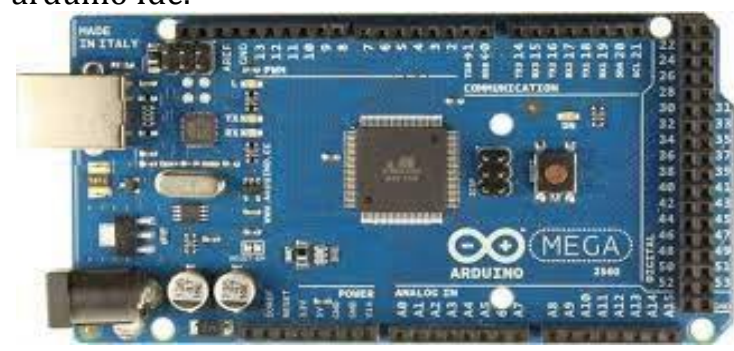

Gambar 1. Arduino Mega
2) Sensor Arus

Dalam pembuatan suatu produk perlu diketahui berapa konsumsi arus dari suatu produk tersebut. Untuk mengetahui berapa nilai arus yang mengalir dalam rangkaian tersebut digunakan sensor arus. Pada pembuatan alat ini digunakan sensor arus jenis sct013, dimana sensor ini bersifat non invansive artinya sensor ini bekerja tanpa harus langsung di sambungkan dengan beban, sensor ini bekerja pada sumber ac dan prinsip kerjanya seperti prinsip kerja tarfo ct.

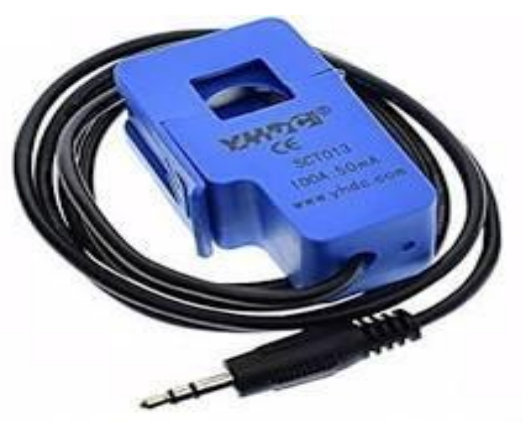

Gambar 2. Sensor Arus Sct013

3) Sensor Tegangan

Pada pembuatan Tugas Akhir ini, sensor tegangan yang digunakan adalah sensor tegangan zmpt101b. Dalam sensor ini terdapat trafo zmpt101b yang berpungsi merubah nilai tegangan dari tengan 220 menjadi sekitar 5volt yang telah dibah menjadi tegangan analog. Sensor ini hanya bekerja pada rangkaian satu phasa ac.

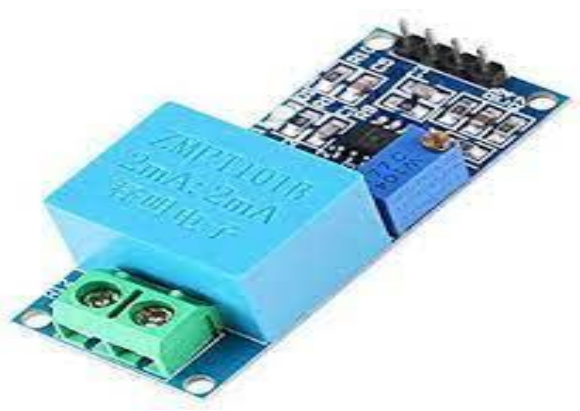

Gambar 3. Sensor Tegangan Zmpt101b

4) Modul Wifi Esp8266-01

Module esp8266-01 adalah modul wifi yang berfungsi untuk menhubungkan system dengan internet. Esp01 ini merupakan salah satu dari jenis esp8266. Pada pembuatan alat ini modul esp8266 ini digunakan untuk menghubungkan rangakaian alat dengan internet, dimana data yang terukur oleh system nantinya akan dikirim ke database yang telah dibuat. 


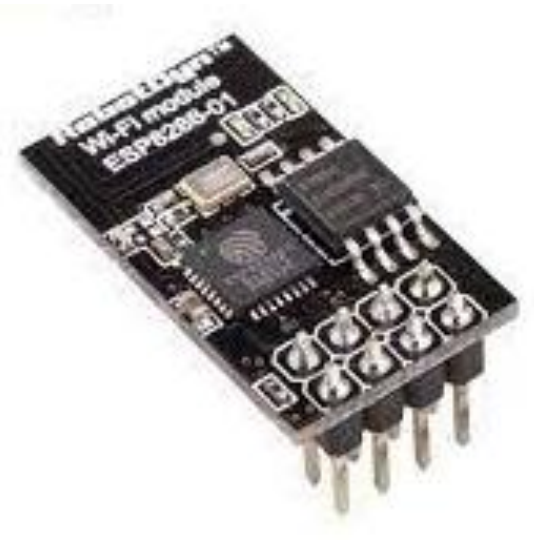

Gambar 4. Modul Esp8266-01

B. Perancangan Dan Pembuatan Alat

1) Blog Diagram

Dalam perancangan suatu system blog diagram berfungsi sebagai gambaran awal dari pembuatan pembuatan suatu system. Dimana di dalam blog diagram tersebut akan tergambarkan prinsip kerja dari system. Dimana blog diagram dari rangkaian alat ini adalah seperti gambar 5 .

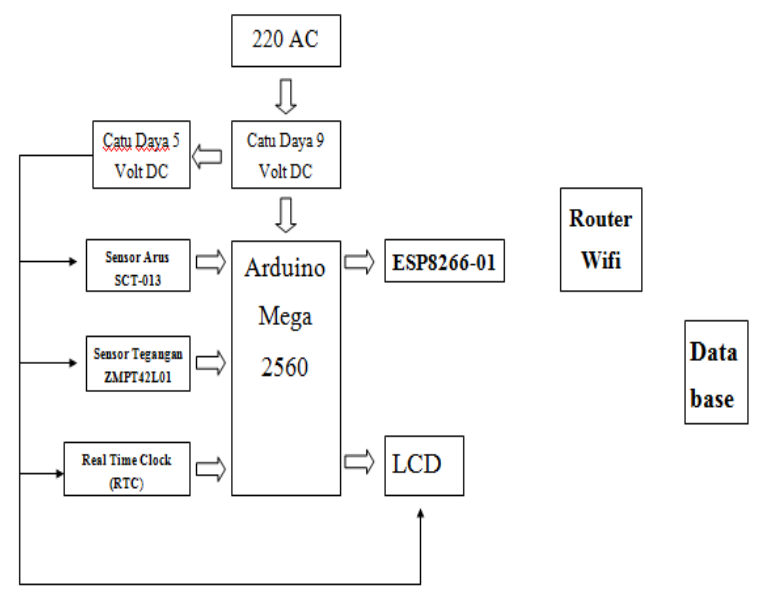

Gambar 5. Blog Diagram Alat

2) Prinsip Kerja Alat

Sebelum pembuatan rangkaian dari alat ini pertama sekali proses kerja dari alat ini digambarakan dalam bentuk flowchart. Dimana gambar 6. Adalah flowcart dari alat moinitoring beban trafo.

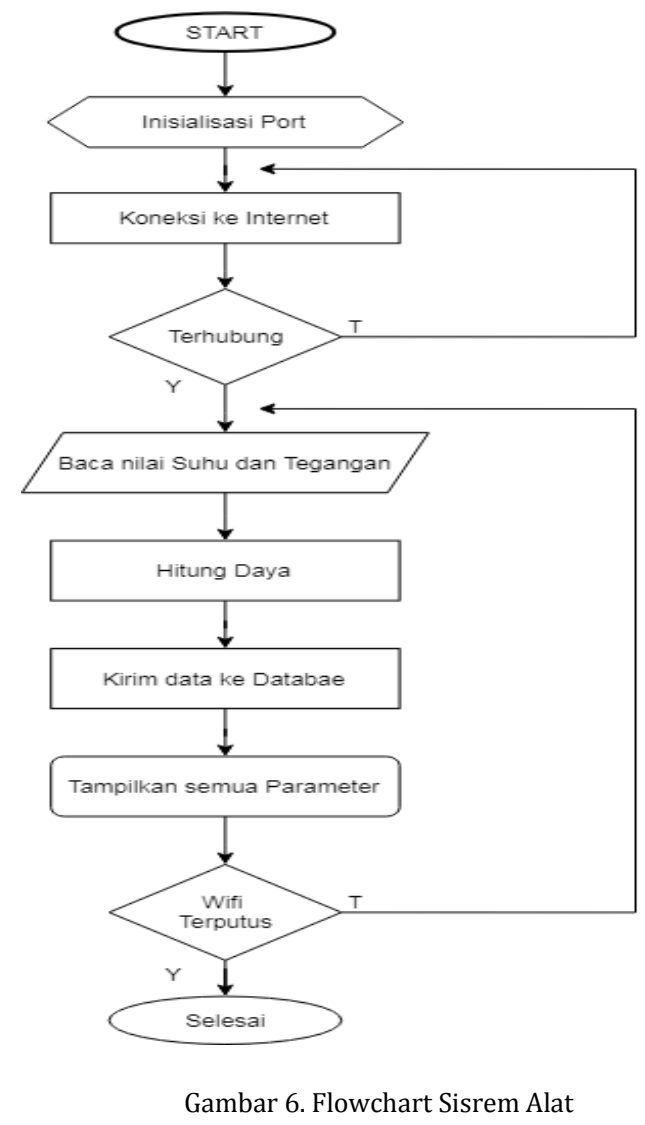

Prinsip kerja dari alat monitoring ini adalah pertama sekali cek semua rangkaian apakah sudah terhubung dengan benar. Sambungkan dengan sumber tegangan, lalu di tekan tombol power untuk system maka alat akan menginisialisasi port. Setelah itu esp8266 akan mencoba terhubung dengan internet yang telah diatur dalam program. Jika sudah terhubung alat akan membaca tegangan dan arus dan dilanjutkan dengan memproses data arus dan tegangan tersebut untuk menghitung daya. Apabila system belum terhubung ke internet, esp01 akan terus menerus mencoba menghubungkan ke internet karena system tidak akan membaca arus dan tegangan sebelum terhubung ke internet. Seteleh dilakukan proses pengolahan data menjadi daya, maka esp01 akan megirimkan data tersebut ke system database dimana databasenya yang terdapat di dalam website dengan alamat alinasution.epizy.com. Proses pengiriman akan mengirim setiap 5 menit sekali karena alat sudah di program membaca arus dan tegangan setiap 5 menit. Jika internet telah terputus maka alat akan sesesai me monitoring dan jika wifi belum terputus proses monitoring akan terus berulang samai internet terputus, dan proses selesai. 
3) Rangkaian Sensor Arus

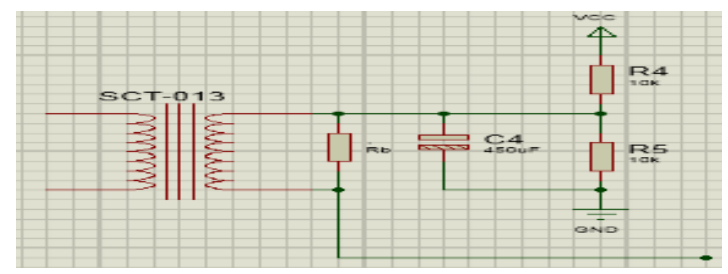

Gambar 7. Rangkaian Sensor Arus

4) Rangkaian Sensor Tegangan

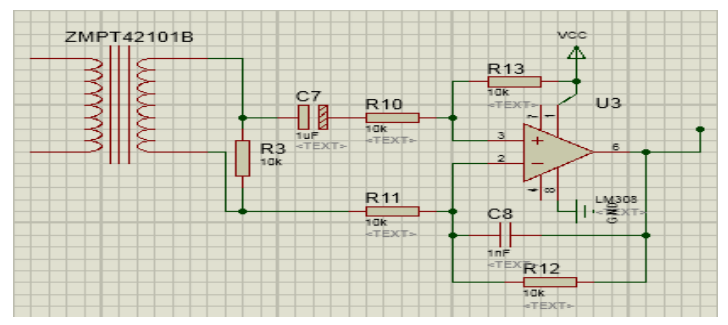

Gambar 8. Rangkaian Sensor Tegangan

5) Rangkaian Esp8266-01

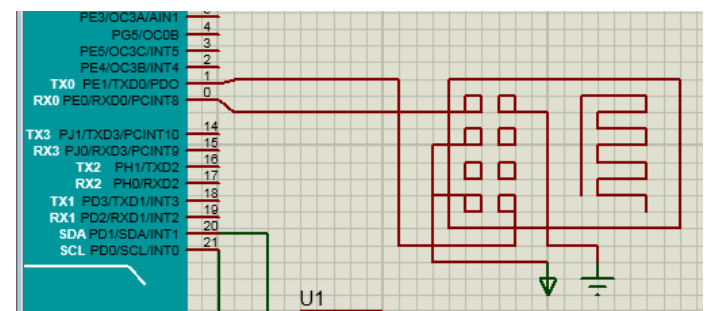

Gambar 9. Rangkaian Esp8266-01

6) Gambar Rangkaian Keseluruhan

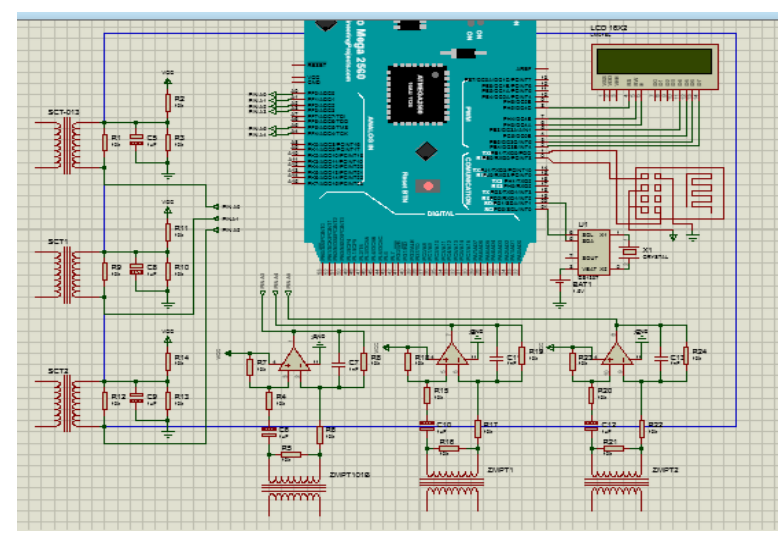

Gambar 10. Rangkaian Keseluruhan
7) Pembutan Database

Setelah program pembacaan alat telah berfungsi maka data tersebut perlu dibuat tempat untuk menampung data tersebut. Maka disini perlu dibuat suatau database. Database dari alat ini dibuat dalam sebuah web yang nantinya akan bias diakses melalui internet. Pembuatan databasenya sendiri pertama dibuat dalam sebuah software yang bernama Xampp, dan xampp ini adalah sebuah server database tapi masih dalam lingkup local, dan belum bersifat online. Setelah databasenya selsesau dibuat maka kemudian di upload ke website yang kita tuju.

8) Pembuatan Tampilan Web

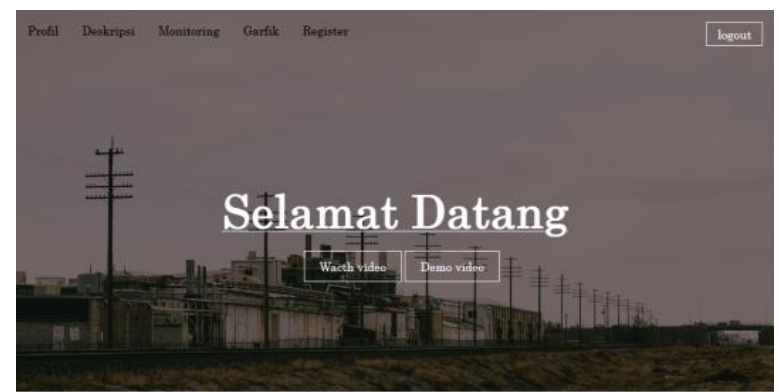

Gambar 11. Tampilan web

Karena database sendiri walaupun sudah di upload, tapi itu belum cukup karena kita masih belum bias melihat isi dari databasenya itu sendiri. Maka dibuata tampilan website tersebut untuk menghubungkan halaman web ke database sehingga isi dari data base tersebut bias dilihat dalam halaman web. Dalam pembuatan tampilan web ini dibuat dengan bahasa html dan php, dimana dalam pembuatan tampilan ini dibuat dalam tiga folder yaitu folder koneksi, folder index dan folder tambah. Ketiga folder tersebut dibuat dalam sebuah software yang bernama visual code studio.

9) Proses Komunikasi

Dalam alat monitoring ini terdapat dua arah komunikasi yaitu pengirim dan penerima, dimana arduino sebagai pengirim dan database sebgai penerima data. Sisi pengiriman dimana cara kerjanya adalah dalam program alat ini ada sebuat sintak yang berfungsi untuk mengirim kedata base, dimana sintak program ini akan mengakses alamat dari database yang dituju. Sintaknya adalah Serial Client :GET/alinasution.epizy.com/include.php?vr= \&vs $=\& \mathrm{vt}=$ \&ir $=$ \&iis $=$ \&it $=$ \&er $=$ \&es $=$ \&et $=$

Pada sisi website terdapat tiga buah file yaitu index.php, connect.php, dan include.php. File include.php akan menerima dari pengirim semua data yang dikirim tadi dan memasukkanya ke 
masing masing variable.Kareba sebelumya variablevariabel tadi sudah di deklarasikan di dalam file include.php sebelumnya.

\section{HASIL DAN PEMBAHASAN}

A. Pengujian Catu Daya

1) Pengujian

Pada pengujian catu daya disini dilakukan pengukuran terhadap output dari catu daya, dimana output dari catu daya terdiri dari dua bua output yaitu 5 volt dan 9volt dc. Adapun hasil pengujiannya adalah

Tabel I. Hasil Pengujian Catudaya

\begin{tabular}{|c|c|c|c|}
\hline $\begin{array}{c}\text { Primer Trafo } \\
\text { (VAC) }\end{array}$ & $\begin{array}{c}\text { Sekunder Trafo } \\
\text { (VAC) }\end{array}$ & $\begin{array}{c}\text { LM7809 } \\
\text { (VDC) }\end{array}$ & $\begin{array}{c}\text { LM7805 } \\
\text { (VDC) }\end{array}$ \\
\hline 232 & 12,6 & 9,0 & 5,0 \\
\hline
\end{tabular}

2) Analisa

Hasil pengujian catu daya yang telah di lakukan, dan didapatkan hasil padatabel diatas. Dari tabel tersebut dapat dilihat bahwa hasil keluaran dari regulator LM7809 dan LM7805 adalah sesuai dengan yang diharapkan, dimana hasil keluaran adalah 9,0 vdc dan 5,0 vdc

B. Pengujian Sensor Tegangan

1) Pengujian

Pengujian sensor tegangan dilakukan dengan membandingkan tegangan yang terbaca oleh sensor dan tegangan yang terbaca oleh voltmeter. Adapun hasil pengujiannya adalah sebagai berikut:

Tabel II. Hasil Pengujian Sensor Tegangan

\begin{tabular}{|c|c|c|c|c|c|}
\hline \multicolumn{3}{|c|}{ Volmeter (V) } & \multicolumn{3}{c|}{ Sensor Tegangan (V) } \\
\hline $\mathrm{R}$ & $\mathrm{S}$ & $\mathrm{T}$ & $\mathrm{R}$ & $\mathrm{S}$ & $\mathrm{T}$ \\
\hline 138 & 136 & 132 & 138,87 & 136,31 & 130,55 \\
\hline 137 & 137 & 131 & 140,4 & 136,71 & 130,98 \\
\hline 136 & 136 & 131 & 139,04 & 135,94 & 130,13 \\
\hline 136 & 136 & 131 & 138,82 & 135,85 & 130,31 \\
\hline 137 & 136 & 132 & 138,59 & 135,77 & 130,14 \\
\hline
\end{tabular}

2) Analisa

Dari pengujian tegangan yang telah dilakukan, bahwa perbandingan hasil pembacaan oleh sensor dan voltmeter memiliki perbedaan, namun perbedaan pembacaan tersebut tidak terlalu signifikan dan masih dalam batas toleransi dari sensor tersebut. Dimana hasil pembacaan sensor tersebut dapat dilihat pada tabel di atas. Dari tabel tersebut dapat di lihat bahwa nilai error tertinggi adaah $2,23 \%$, dimana error tersebut masih dalam range toleransi dari modul sensor tersebut.
C. Pengujian Sensor Arus

1) Pengujian

Table III. Hasil Pengujian Sensor Arus

\begin{tabular}{|c|c|c|c|c|c|c|}
\hline \multirow{2}{*}{ NO } & \multicolumn{3}{|c|}{ Amperemeter (A) } & \multicolumn{3}{c|}{ Sensor Arus (A) } \\
\cline { 2 - 7 } & $\mathrm{R}$ & $\mathrm{S}$ & $\mathrm{T}$ & $\mathrm{R}$ & $\mathrm{S}$ & $\mathrm{T}$ \\
\hline 1 & 1,53 & 2,07 & 1,87 & 1,57 & 2,09 & 1,89 \\
\hline 2 & 1,88 & 2,05 & 1,85 & 1,57 & 2,09 & 1,89 \\
\hline 3 & 1,78 & 2.25 & 2,03 & 1,8 & 2,29 & 2,08 \\
\hline 4 & 1,81 & 2,3 & 2,07 & 1,8 & 2,28 & 2,08 \\
\hline 5 & 1,79 & 2,22 & 2,09 & 1,8 & 2,29 & 2,08 \\
\hline
\end{tabular}

2) Analisa

Dari tabel hasil pengujian sensor arus diatas dapat dilihat bahwa perbandingan pembacaan nilai arus oleh sensor dan oleh amperemeter terdapat perbedaan nilai pembacaan. Dari tabel dapat dilihat bahwa nilai error paling tinggi adalah 3,15\%, dan ini merupakan error yang masih dalam range toleransi sensor.

D. Pengujian Modul Wifi Esp8266-01

1) Pengujian

Pada pengujian modul esp01 adalah melukan pengujian apakah esp dapat terhubung ke internet yang tersedia. Hasil dari pengujian adalah gambar 12:

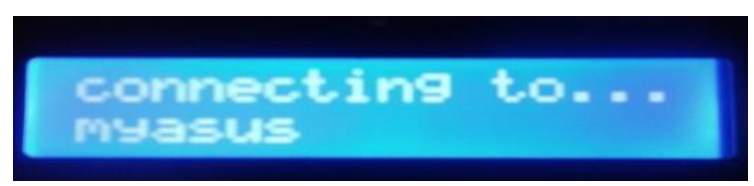

Gambar 12. Modul Esp Mencoba Terhubung Ke Jaringan

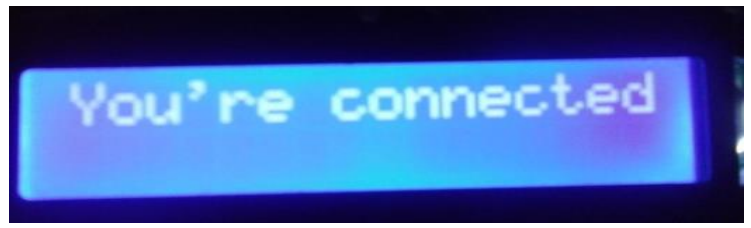

Gambar 13. Modul Esp Mencoba Terhubung Ke Jaringan

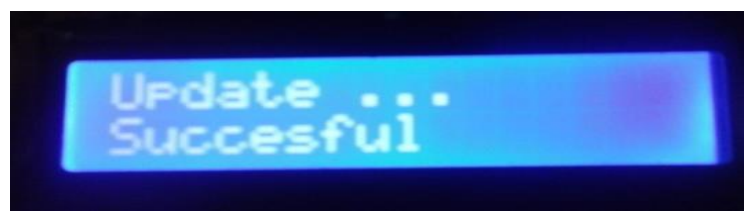

Gambar 14. Modul Esp Mengirim Data Ke Database 
2) Analisa

Dari gambar diatas bisa dilihat bahwa module esp8266 mencoba terhubung dengan jaringan yang telah di atur. Setelah module esp berhasil terhubung ke jaringan maka data variabel yang diolah di arduino akan dikirim ke database, esp akan megirim variabel dan dari gambar 17. terlihat bahwa pengiriman berhasil yang ditandai dengan tulisan update successful.

E. Analisa Pembebanan Trafo

Diketahui:

$\mathrm{S}=2 \mathrm{KVA}=2000 \mathrm{VA}$

$\mathrm{V}($ fasa-fasa $)=236 \mathrm{~V}$

$$
\mathrm{I}_{\mathrm{FL}}=\frac{S}{\sqrt{3 * V}}
$$

$\mathrm{I}_{\mathrm{FL}}=\frac{S}{\sqrt{3 * V}}=\frac{2000}{408,76}=4,89 \mathrm{~A}$

1) Pada Saat Beban $R=40 K, S=20 K, T=40 K$

Persentase Pembebanan Trafo

$$
\text { I rata-rata }=\frac{\mathbf{I R + I S + I T}}{3}
$$

I rata-rata $=\frac{1,8+2,29+1,08}{3}$

$$
=2,05 \mathrm{~A}
$$

$$
\text { Pembebanan Trafo }=\frac{\text { Irata }- \text { rata }}{I F L} \times 100 \%
$$

Persentase Pembebanan trafo $=\frac{2,05}{4,89} \times 100 \%$

$$
=41,92 \%
$$

Analisis Ketidak Seimbangan Trafo

$$
\mathrm{a}=\frac{\mathrm{I}}{\text { Irata-rata }}
$$

$\mathrm{a}=$ Ketidak Seimbangan Trafi (A)

$\mathrm{I}=$ Ars Fasa (V)

$$
\begin{array}{ll}
\text { IR=a * Irata-rata } & \mathrm{a}=\frac{\mathbf{1 , 8}}{2,05}=0,88 \mathrm{~A} \\
\text { IS=a * Irata-rata } & \mathrm{a}=\frac{\mathbf{2 , 2 9}}{\mathbf{2 , 0 5}}=1,11 \mathrm{~A} \\
\text { IT }=\mathrm{a} \text { * Irata-rata } & \mathrm{a}=\frac{\mathbf{2 , 0 8}}{\mathbf{2 , 0 5}}=1,01 \mathrm{~A}
\end{array}
$$

Persentase Ketidak Seimbangan Trafo

$=\frac{\{|a-1|+|b-1|+|c-1|\}}{3} \times 100 \%$ $=\frac{\{|0,88-1|+|1,11-1|+|1,01-1|\}}{3} \times 100 \%$

$=0,33 \%$

2) Pada Saat Beban $R=20 K, S=20 K, T=20 K$

Persentase Pembebanan Trafo

I rata-rata $=\frac{I R+I S+I T}{3}=\frac{1,57+2,09+1,89}{3}=1,85 \mathrm{~A}$

Persentase Pembebanan Trafo $=\frac{\text { Irata }- \text { rata }}{I F L} \times 100 \%$

$$
\begin{aligned}
& =\frac{1,85}{4,89} \times 100 \% \\
& =37,83 \%
\end{aligned}
$$

Analisis Ketidak Seimbangan Trafo

$$
\begin{array}{ll}
\text { IR=a * Irata-rata } & a=\frac{\mathbf{1 , 5 7}}{\mathbf{1 , 8 5}}=0,85 \mathrm{~A} \\
\text { IS }=\mathrm{a} * \text { Irata-rata } & \mathrm{a}=\frac{\mathbf{2 , 0 9}}{\mathbf{1 , 8 5}}=1,13 \mathrm{~A} \\
\text { IT }=\mathrm{a} \text { * Irata-rata } & \mathrm{a}=\frac{\mathbf{1 , 8 9}}{\mathbf{1 , 8 5}}=1,02 \mathrm{~A}
\end{array}
$$

Persentase Ketidak Seimbangan Trafo

$=\frac{\{|a-1|+|b-1|+|c-1|\}}{3} \times 100 \%$

$=\frac{\{|\mathbf{0 , 8 5}-\mathbf{1}|+|\mathbf{1}, \mathbf{1 3}-\mathbf{1}|+|\mathbf{1}, \mathbf{0 2}-\mathbf{1}|\}}{3} \times 100 \%$

$=0 \%$

\section{KESIMPULAN}

Hasil dari pengujian dan analisa alat monitoring beban trafo berbasis web ini adalah bahwa alat sudah bekerja sesuai yang di harapkan. Dimana setelah melakukan pengujian pembacaan tegangan dan arus menggunakan sensor dan membandingkan dengan pembacaan tegangan dan arus secara manual dengan alat ukur didapatkan hasil tidak sama persis degan pembacaan alat ukur dan terdapat perbedaan hasil pengukuran, tetapi masih dalam batas toleransi modul tersebut tersebut. Dan pengujian modul esp sudah bekerja dengan maksimal dimana modul sudah bisa terhubung ke internet dan dapat melakukan pengiriman data ke database. Pada pengujian catu daya didapatkan hasil yang bisa dikatakan cukup sempurna karena hasil yang didapatkan pada output adaah sesuai dengan kerja regulator tersebut, dimana hasil yang didapatkan adalah 9,0 vdc dan 5,0 vdc. Setelah melakukan pengujian alat dan setelah di analisa, bahwa dalam alat monitoring beban rafo tiga fasa berbasis web ini masih terdapat banyak sisi kekurangannya. Baik dari segi hardware maupun dari segi software, dimana kekurangannya dari segi hardware, ukurannya harusnya 
seminimalis mungkin, sensor-sensor-nya yang masih kurang presisi pembacaannya, dan sensor tegangan pembacaannya masih per phasa belum bisa membaca antara phasa. Dan tugas akhir ini masih perlu pengembangan.

\section{REFERENSI}

[1] M. Dwiyanto and T. Sogen, "Analisis Pengaruh Ketidakseimbangan Beban Terhadap Arus Netral Dan Losses Pada Transformator Distribusi Di Pt Pln ( Persero ) Area Sorong," vol. 4, no. 1, pp. 1-10, 2018.

[2] T. Kv, B. Arduino, and B. Winardi, "Perancangan Monitoring Suhu Transformator."

[3] K. Sari, "Monitoring Transformator Distribusi Berbasis Skripsi Oleh :," 2019.

[4] J. Ohoiwutun, M. Dwiyanto, and T. Sogen, "Analisis Pengaruh Ketidakseimbangan Beban Terhadap Efisiensi Transformator Distribusi 100 Kva Pada Pt . Pln ( Persero ) Unit Aimas Analysis Of The Influence Of Load Balance In The Efficiency Of 100 Kva Distribution Transformers In Pt. Pln ( Persero ) Aim," vol. 5, no. 2, 2019.

[5] Gamma Ayu Kartikasari, "Gamma Ayu Kartikasari," Anal. Pengaruh Ketidakseimbangan Beban Terhadap Arus Netral Dan Losses Pada Trafo Distrib. Stud. Kasus Pada Pt. Pln Rayon Blora , pp. 1-14, 2018.

[6] L. Frisila, "Perancangan Prototipe Real Time Monitoring Berbasis Mikrokontroler," vol. 15, no. 1, pp. 55-64, 2017.

[7] H. Nimpa and H. Sutejo, "Pengembangan Sistem Informasi Pengukuran Gardu Distribusi PLN Berbasis Android," Knsi 2018, pp. 310-315, 2018.
[8] B. Rahardy, D. E. A. Priyadi, S.T., M.Eng., and P. D. I. M. Hery P., M.Eng., "Monitoring Kondisi Transformator Daya Secara Online Berbasis Analisis Data Suhu, Tegangan, dan Arus pada Transformator Distribusi," no. 1, pp. 1-6, 2012.

[9] A. R. Madjid and B. Suprianto, "Prototype Monitoring Arus , Dan Suhu Pada Transformator Distribusi Berbasis Internet Of Things ( IoT )," Jur. Tek. Elektro Fak. Tek. Univ. Negeri Surabaya, pp. 111-119, 2019

[10] Z. Abidin and M. Baha'udin, "Monitoring Dan Proteksi Tegangan Panel 3 Fasa Dengan Menggunakan Sensor Tegangan ZMPT101B," pp. 1-8.

\section{Biodata Penulis}

Ali Usman Nasution, lahir di Pidoli Lombang, 23 Juni 1997. Sarjana Saints Terapan, di Jurusan Teknik Elektro Program Studi DIV Teknik Elektro Industri, Fakultas Teknik, Universitas Negeri Padang. Sejak tahun 20162020.

Sukardi, lahir di Kerinci, 10 Mei 1961. Menyelesaikan pendidikan S1 jurusan teknik elektro di IKIP Padang Indonesia dan pendidikan Pascasarjana (S2) Magister Teknik Elektro di ITB dan gelar Doktor (S3) Pendidikan Teknologi Kejuruan di UNY. Staf pengajar pada Jurusan Teknik Elektro FT UNP sejak tahun 1986 - sekarang. 